\title{
OCCURRENCE OF CONTAMINANT BIOTA IN DIFFERENT EUROPEAN DRY-SAUSAGES
}

\author{
M. C. LÓPEZ, L. M. MEDINA, R. HUERTA and R. JORDANO \\ Departamento de Bromatología y Tecnología de los Alimentos, Universidad de Córdoba, \\ Campus de Rabanales. E-14071 Córdoba. Spain
}

(Received: 14 September 1999; accepted: 16 January 2000)

\begin{abstract}
The aim of this work was to study in six different types of European dry-sausages (of the Mediterranean area) the ocurrence of contaminant biota: enterobacteria, coliforms, E. coli, enterococci, sulphite-reducing clostridia, Salmonella-Shigella and Listeria monocytogenes, in the course of the ripening process. A total of 162 samples were analysed at different stages of the elaboration process. These were grouped in eighteen lots, three for each type of dry-sausages. Throughout the ripening process a decrease in some microbe groups (enterobacteria, coliforms, E. coli) occurred in all cases. Yeasts and enterococci remained the same or even increased in number. We have also confirmed the presence of Salmonella, sulphite-reducing clostridia and Listeria in some samples of unripened product. Consequently, an improvement could be desirable in the hygienic quality of the raw material of dry-sausages. Nevertheless, the final products analysed showed an acceptable state of food safety in all cases.
\end{abstract}

Keywords: contaminant biota, dry-sausages

Dry-fermented sausages are common traditional meat products in many countries, especially in the Mediterranean zone (SAMELIS et al., 1994).

The microflora found initially in the mass of the sausages is enormously varied and its sources are very heterogeneous because of the contribution of all the ingredients (POZO, 1985). Contamination can take place during primary production of raw materials of plant and animal origin. In addition, it may occur during and after processing as a result of inadequate hygiene or packaging practices (NOUT, 1994).

It should be assumed that most common foodborne pathogenic microorganisms could be encountered in raw meats. Many fermented meat products are often held at

\footnotetext{
a To whom the correspondence should be addressed

Departamento de Bromatología y Tecnología de los Alimentos,

Campus Universitario de Rabanales. Edificio C-1 Anexo. Ctra. NIV Km 396.A,

E-14071 Córdoba (Spain),

Tel. +34 957 212006, Fax +34 957 212000, E-mail bt1josar@uco.es
} 
elevated temperatures during processing to ensure rapid fermentation, but these temperatures can also accentuate the growth of pathogenic bacteria, so that a strict control of the product is essential (BACUS \& BROWN, 1981).

The conditions established in dry-sausages during the ripening: low $\mathrm{pH}$, reduced $\mathrm{a}_{\mathrm{w}}$, anaerobic conditions and the presence of starter cultures have an inhibitory effect on contaminant biota, since an inversion of the initial microbial population from Gram-negative to Gram-positive is produced. However, a lethal effect in pathogens which would guarantee the harmlessness of the product is not really established (ADAMS $\&$ Moss, 1997). Therefore, it is essential to use raw materials of good quality that in combination with the proper processing controls guarantee the safety and quality of the final product.

Contrary to what it could be thought, food-borne diseases are increasing rather than decreasing even in countries with a large supply and variety of cheap foods. Meat regularly contains pathogenic bacteria, and the ingestion of fermented sausages has occasionally resulted in outbreaks of illness (LÜCKE, 1994).

Many undesirable microorganisms are incapable of growing under these conditions. During the initial stages of microbial fermentation, the number of Enterobacteriaceae usually remains constant, and as drying of the sausages progresses, Enterobacteriaceae, including Salmonella, are slowly inactivated. Salmonella typhimurium may survive in raw cured sausages if only marginal acidification takes place and it is combined with high moisture content. For instance, a minor outbreak of salmonellosis was caused by fermented pork sausages (VAN NETTEN et al., 1986). However, its scarce occurrence in dry-fermented sausages suggests that these products are not the most responsible for the foodborne outbreaks caused by Salmonella (VALLADARES et al., 1993).

Clostridia are also inhibited by the process associated with curing the sausages, because Clostridium botulinum is inhibited at low $\mathrm{pH}$ and reduced water activity values and it is also sensitive to nitrite, either added as such or formed by the reduction of nitrate. However, errors during the manufacture of sausages can mean risks of foodborne infections and intoxications. Therefore, an initial high $\mathrm{a}_{\mathrm{w}}$ value and $\mathrm{pH}$, a small number of lactobacilli in the sausage mixture at the beginning of curing and high fermentation temperatures, tend to help the growth of undesirable microorganisms (BELLO \& SÁNCHEZ, 1995).

There has been much concern over the association of Escherichia coli with meats, and recently, with fermented meat products. After an outbreak of E. coli disease which was linked to a dry fermented salami (ANON., 1995) several laboratories researched on the viability of this pathogen in a variety of fermented meats. Up to date it seems that fermentation and drying are only sufficient to reduce about two logarithmic units the numbers of $E$. coli during the manufacture of dry-sausages (FAITH et al., 1997). 
With regard to Listeria monocytogenes, its occurrence throughout the manufacturing process in dry-fermented sausages has been reported in several studies (FARBER et al., 1988; JOHNSON et al., 1988; TRUSSEL \& JEMMI, 1989). In addition, there have been recent sporadic cases of listeriosis linked to meat products such as homemade sausages (CANTONI et al., 1989) and pork sausage (PARODI et al., 1990). Although there are no reports of listeriosis outbreak linked with the consumption of fermented meat products, the high mortality rate (LOVETT, 1989) has led health authorities to be very concerned about the number of this microorganism in meat products (HuGAS et al., 1995).

The aim of this work was to study in different types of European dry-sausages the presence of contaminant biota: enterobacteria, coliforms, E. coli, enterococci, sulfitereducing clostridia, Salmonella-Shigella and L. monocytogenes, in the course of the ripening process.

\section{Material and methods}

\subsection{Sampling}

A total of 162 samples of dry-sausages belonging to six different types were analysed (Table 1), grouped in eighteen lots, three for each type of dry-sausages. Products $A$ (lots $\left.A_{1}, A_{2}, A_{3}\right)$ and $B\left(B_{1}, B_{2}, B_{3}\right)$ were produced by an Italian factory, products $\mathrm{C}$ (lots $\mathrm{C}_{1}, \mathrm{C}_{2}, \mathrm{C}_{3}$ ) and $\mathrm{D}$ (lots $\mathrm{D}_{1}, \mathrm{D}_{2}, \mathrm{D}_{3}$ ) by a French and products $\mathrm{E}$ (lots $E_{1}, E_{2}, E_{3}$ ) and $F\left(\right.$ lots $F_{1}, F_{2}, F_{3}$ ) by a Spanish one. For each lot, three analyses were carried out: unripened product, end of first part of ripening and end product. For each analysis three samples were tested. The transport of the samples was carried out under refrigerated conditions $\left(4 \pm 1^{\circ} \mathrm{C}\right)$.

\subsection{Microbial analysis}

Enterobacteriaceae enumeration was determined on Violet Red Bile Glucose agar (VRBG - Oxoid, Unipath Ltd., Basingstoke, UK) incubated at $35-37{ }^{\circ} \mathrm{C}$ for $21 \pm 3 \mathrm{~h}$.

Enumeration of enterococci: Enumeration was done using Slanetz Bartley medium (Oxoid) at $37{ }^{\circ} \mathrm{C}$ for $48 \mathrm{~h}$. The API 20 Strep System (BioMérieux, La Balme Les grottes, 38390 Montalieu-Vercieu, France) was utilised for identification.

Isolation and identification of Salmonella: Twenty-five grams of sample was suspended in $225 \mathrm{ml}$ of lactose broth (Oxoid) and incubated at $35-37^{\circ} \mathrm{C}$ during 18-24 h. The culture was enriched in selenite broth base with $4 \%$ of sodium biselenite (Oxoid) incubated at $43{ }^{\circ} \mathrm{C}$ for $24 \mathrm{~h}$ and plated on brilliant green agar (Oxoid) and bismuth sulphite agar (Oxoid) at $35-37^{\circ} \mathrm{C}$ for $24-48 \mathrm{~h}$. The colonies suspected of being Salmonella were identified by biochemical and serological tests for this genus, and by the API 20 E System (BioMérieux). 
Isolation and identification of L. monocytogenes: Twenty-five grams of sample was suspended in $225 \mathrm{ml}$ of $1 \%$ bacto peptone (Oxoid) water and incubated at $35-37{ }^{\circ} \mathrm{C}$ for $24 \mathrm{~h}$. The culture $(1 \mathrm{ml})$ was enriched in $10 \mathrm{ml}$ of tryptose broth (Difco Laboratories, Detroit, MI, USA) at $35-37^{\circ} \mathrm{C}, 24 \mathrm{~h}$ and plated on Palcam agar (Oxoid) at $35-37^{\circ} \mathrm{C}$ for $24 \mathrm{~h}$. The API 20 Strep System (BioMérieux) was utilised for identification.

Enumeration and identification of Clostridium spp.: The enumeration was carried out on sulphite polymyxin sulphadiazine agar (SPS - Merck, Darmstadt, Germany) at $46{ }^{\circ} \mathrm{C}$ for $24-48 \mathrm{~h}$ in anaerobic conditions. The identification was carried out by the API 20 A System.

Enumeration of coliforms and identification of E. coli: Coliforms, E. coli, and other Gram-negatives were found using Coli ID (BioMérieux) medium at $37^{\circ} \mathrm{C}$ for $24-48 \mathrm{~h}$.

\section{Results and discussion}

In all studied lots throughout the ripening process a decrease (which was presumably due to the declining evolution of the $\mathrm{pH}$ and the increasing of $\mathrm{NaCl}$ percentage throughout the process) occurred in some microbe groups (enterobacteria, coliforms, E. coli). However, yeasts and enterococci, and in several lots also the group of other Gram-negatives remained the same or even increased in number. The final result was, therefore, the growth of Gram positive biota in detriment to the Gram-negative.

Table 1

Description of the types of dry-sausages analyzed $(\mathrm{n}=162)$

\begin{tabular}{|c|c|c|c|c|c|c|}
\hline Types & $\mathrm{A}^{\mathrm{a}}$ & $\mathrm{B}^{\mathrm{a}}$ & $C^{a}$ & $\mathrm{D}^{\mathrm{a}}$ & $E^{a}$ & $\mathrm{~F}^{\mathrm{a}}$ \\
\hline External diameter $(\mathrm{mm})$ & $55-60$ & 90 & $55-60$ & 100 & $50-55$ & 80 \\
\hline Casing & natural & artificial $^{b}$ & natural & natural & natural & artificial $^{\mathrm{b}}$ \\
\hline Grinding size (mm) & 8 & 3.5 & 7 & 7 & 5 & 5 \\
\hline Duration of ripening ${ }^{\mathrm{c}}$ (days) & 15 & 60 & 30 & 60 & 15 & 30 \\
\hline
\end{tabular}

a 3 lots $\times 3$ samplings $\times 3$ replicates $(n=27)$

${ }^{\mathrm{b}}$ Collagen

${ }^{\mathrm{c}}$ Different commercial starters were added

The results of contaminant biota studied in lots $\mathrm{A}, \mathrm{B}, \mathrm{C}, \mathrm{D}, \mathrm{E}$ and $\mathrm{F}$ are shown in Tables 2, 3, 4, 5, 6 and 7, respectively. The maximum values of $\mathrm{NaCl}$ percentage were found between 2.5 (product F) and 4.78 (product C). 


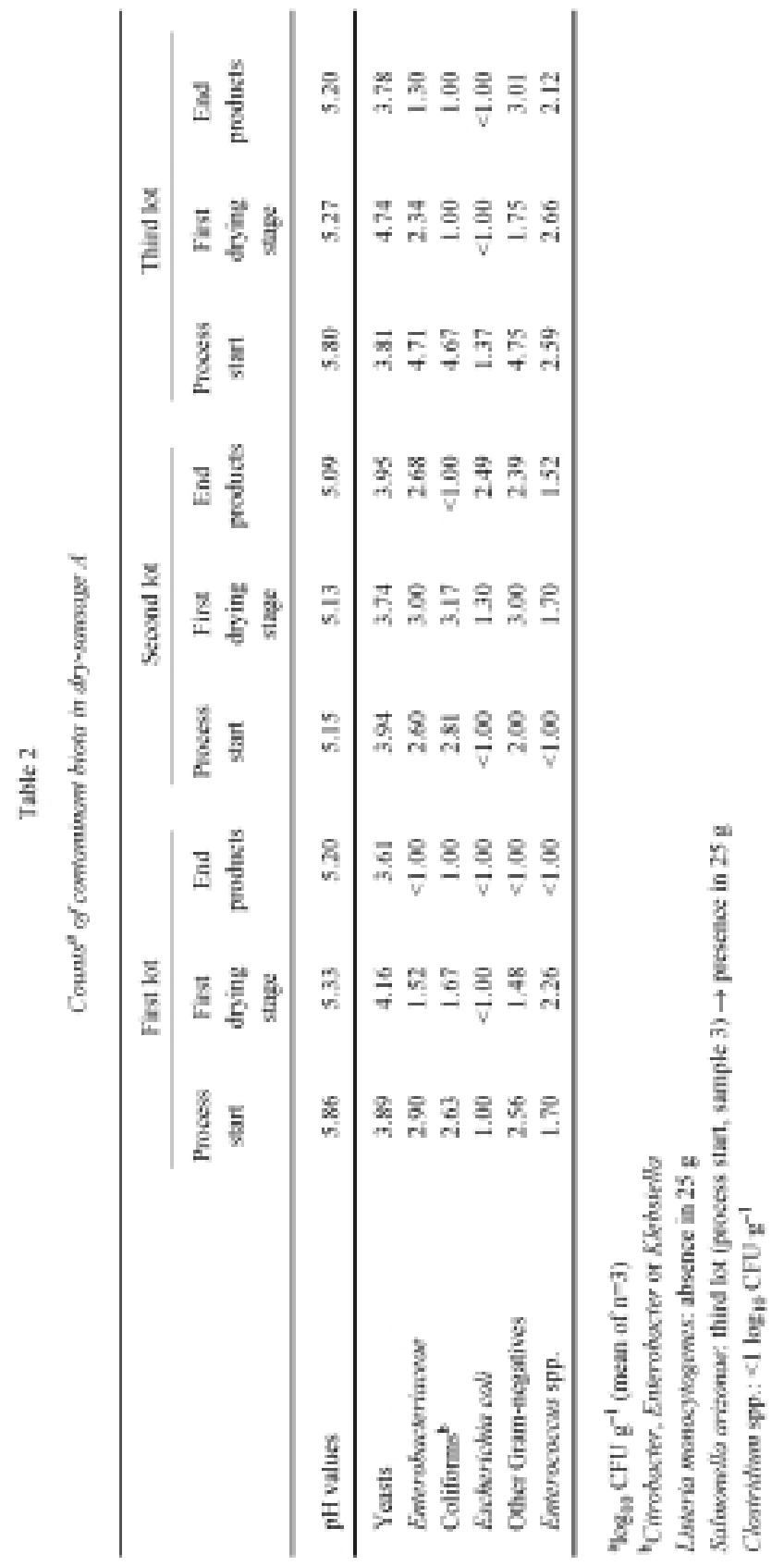




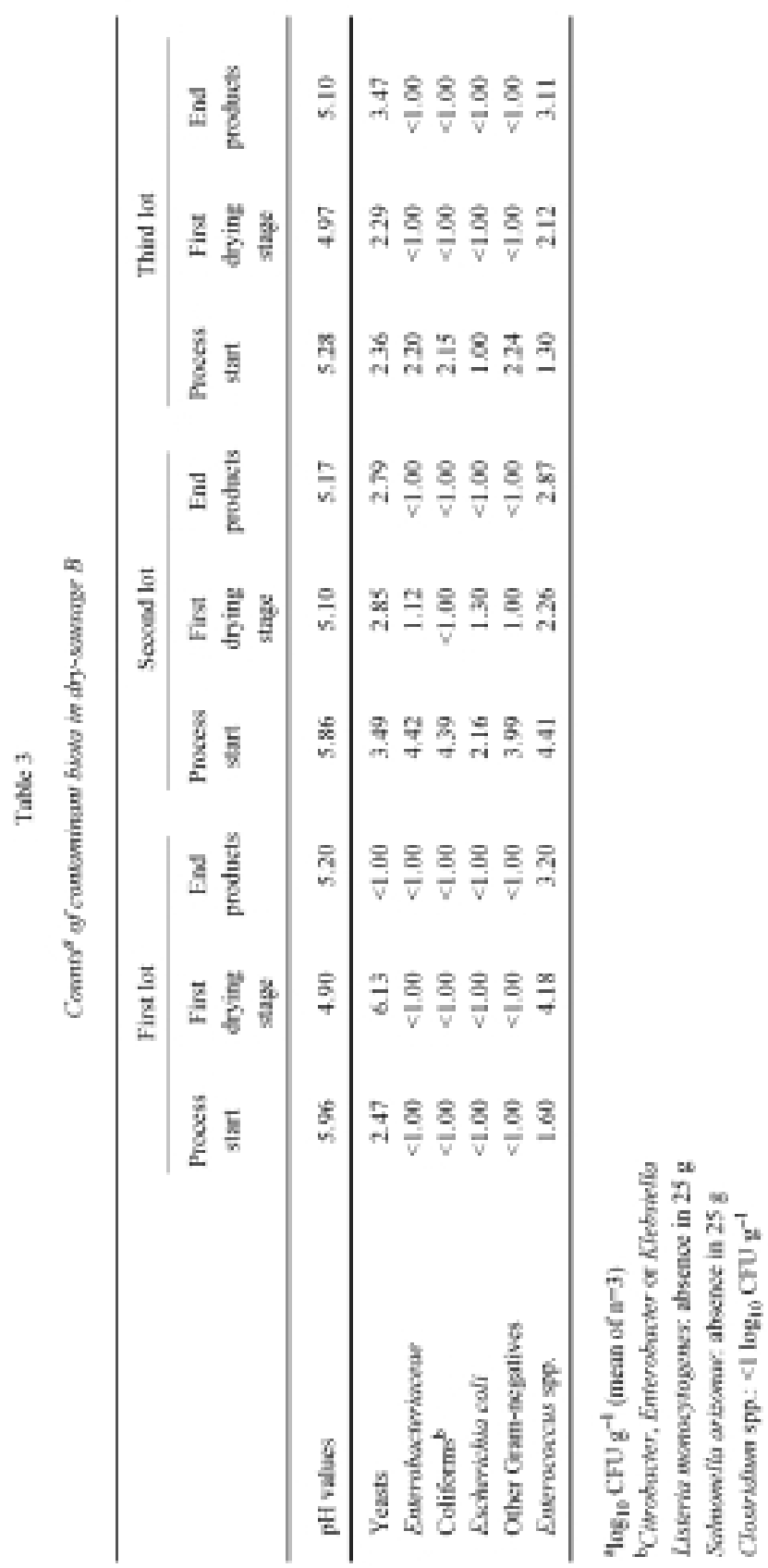




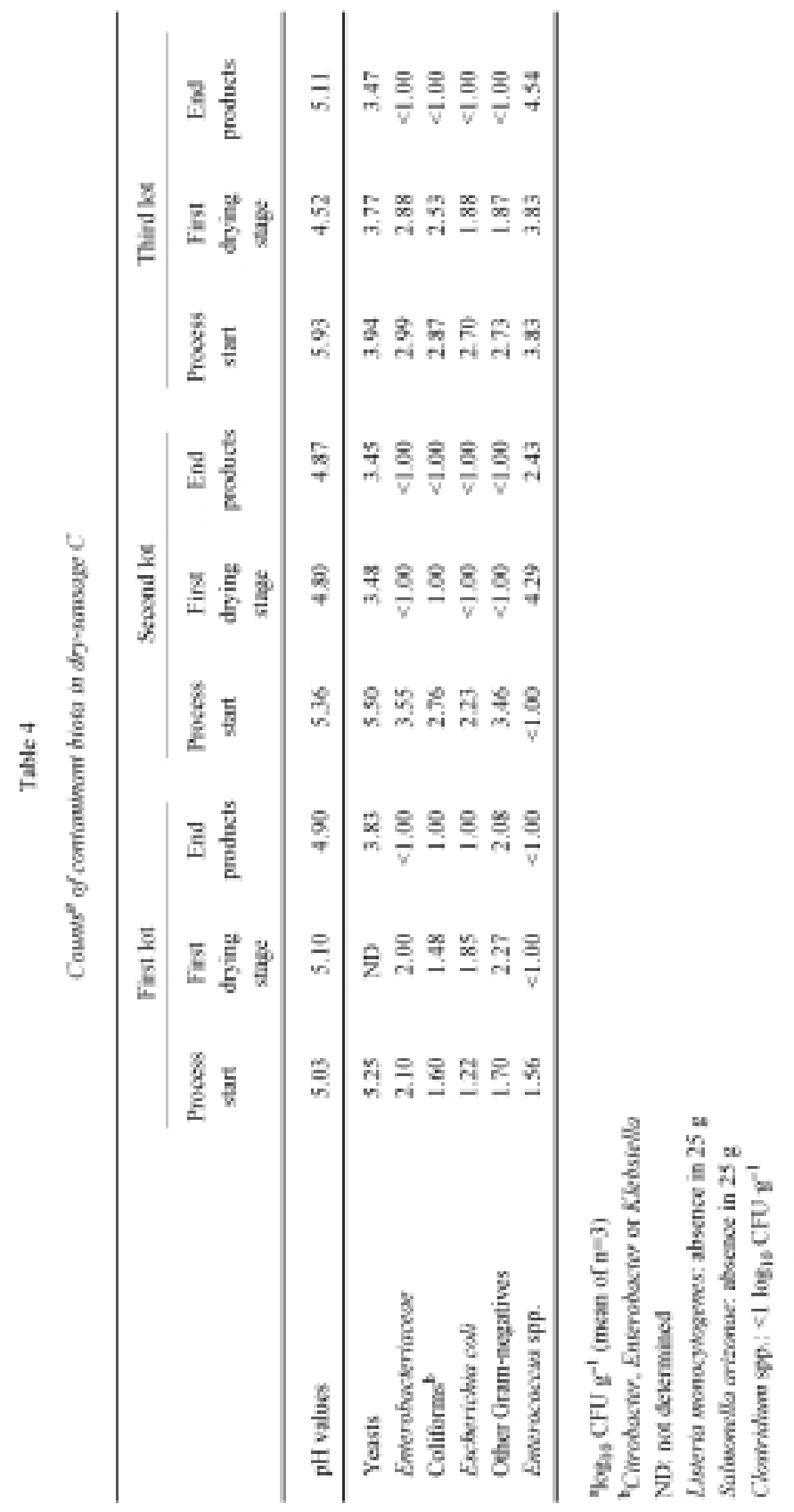




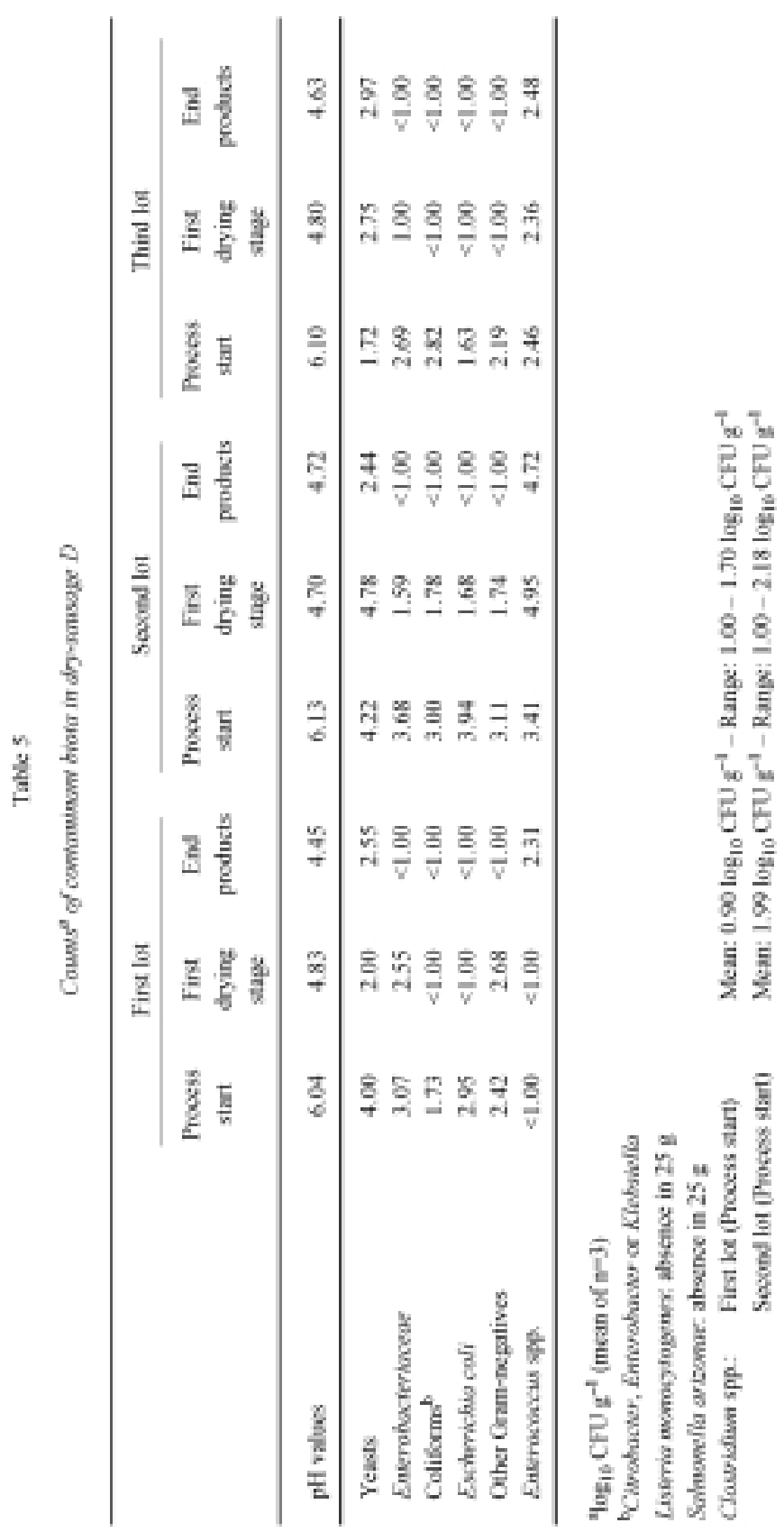

Acta Alimentaria 29, 2000 


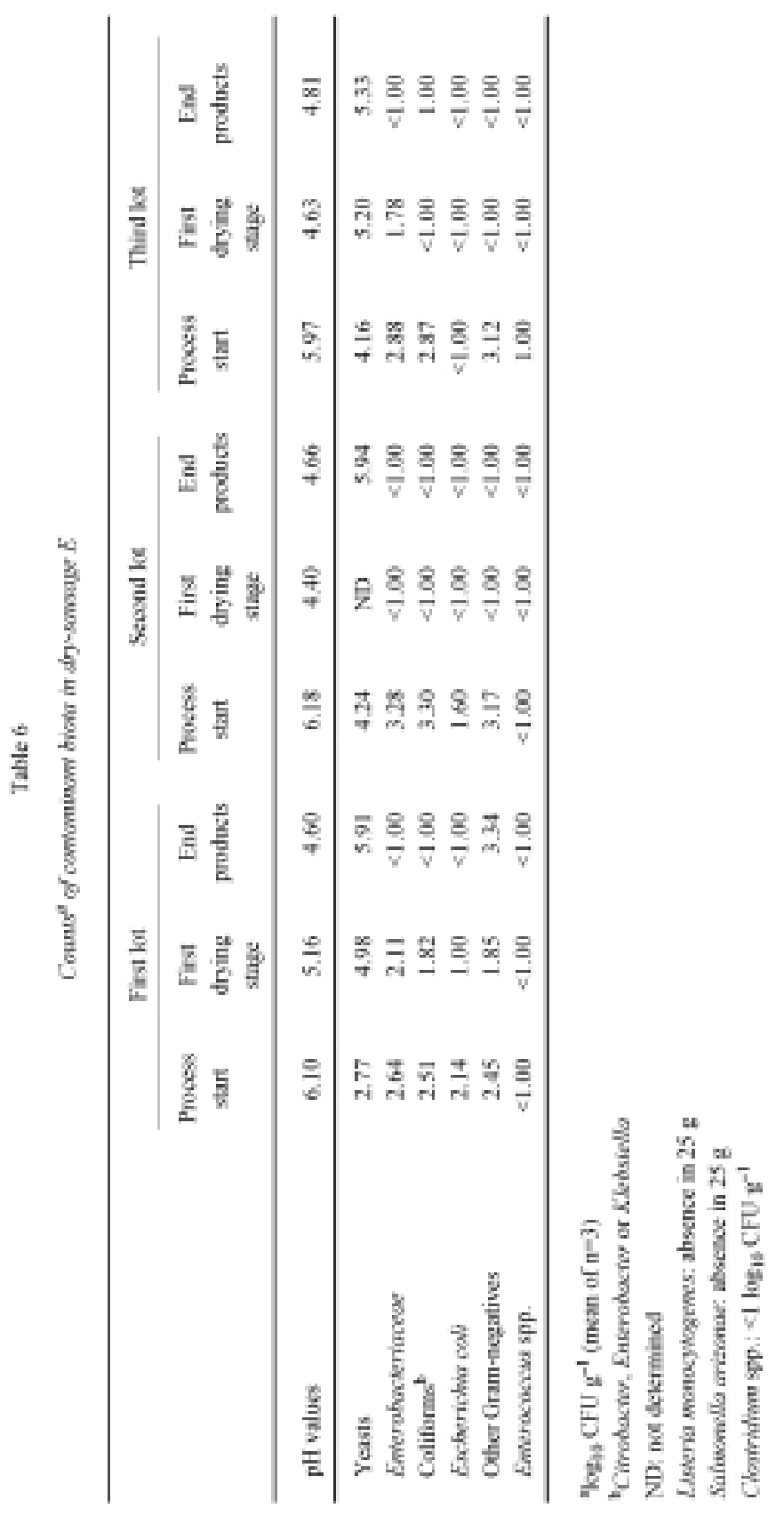




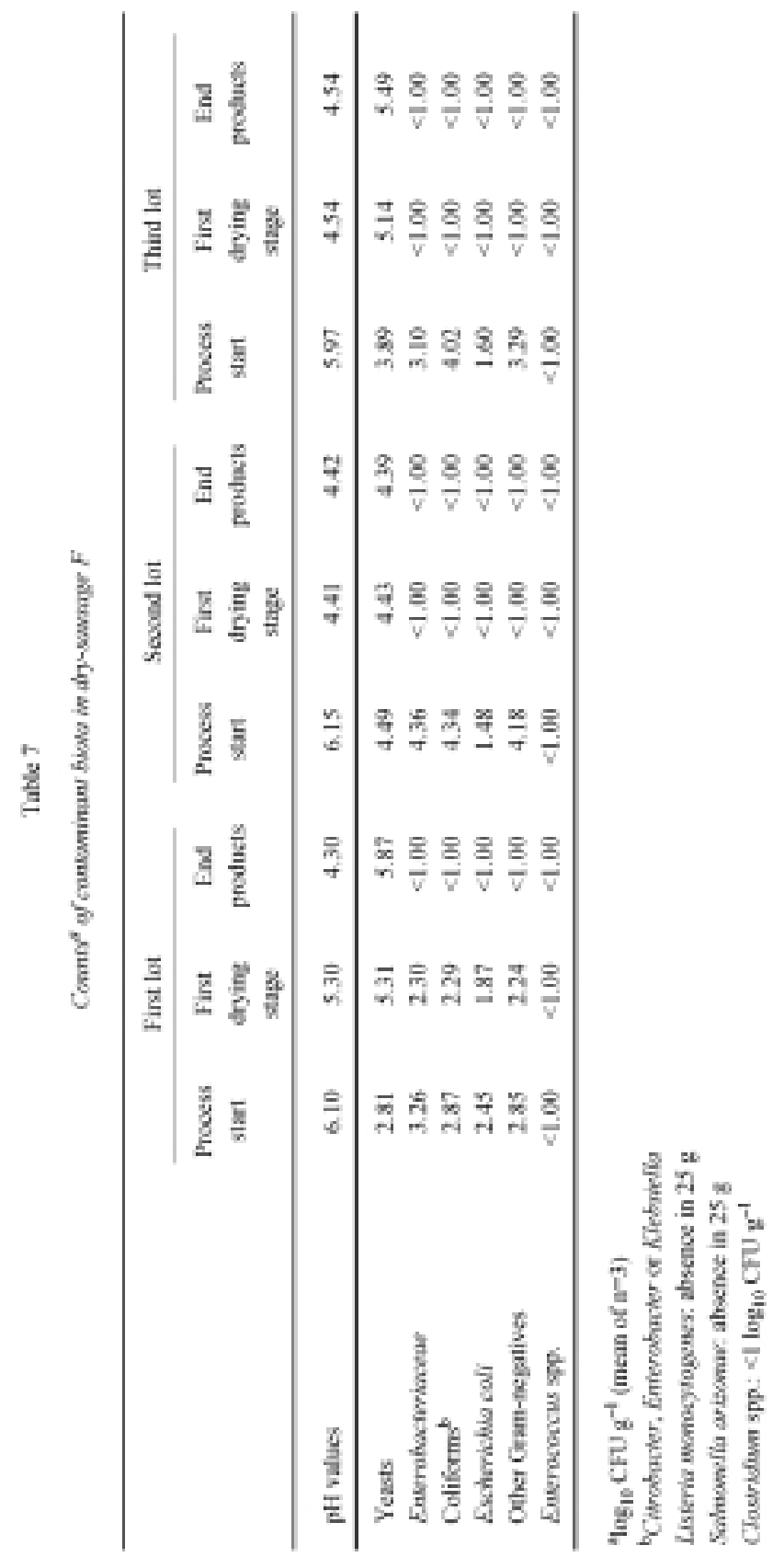




\subsection{Enterobacteriaceae, coliforms, E. coli and other Gram-negative microorganisms counts}

Enterobacteria occurred in $57.4 \%$ of the samples studied and the maximum value was $4.71 \log \mathrm{CFU} \mathrm{g}^{-1}$ in the process start of lot $\mathrm{A}_{3}$. We can consider that they show a decreasing trend in all the lots, with the exception of lot $A_{2}$ where counts are very similar in the three steps. In lot $\mathrm{B}_{1}$ enterobacteria were not detected from the beginning of the process.

Coliforms were found in $55.5 \%$ of the samples, and their counts were, in general, comparable to those of Enterobacteriaceae. The maximum was 4.67 in lot $\mathrm{B}_{3}$ (process start). The evolution of coliforms throughout the ripening process is clearly decreasing with some irregularities in lots $\mathrm{A}_{2}$ and $\mathrm{E}_{3}$. In lot $\mathrm{B}_{1}$ coliforms were not detected.

E. coli was detected in $46.2 \%$ of the samples studied, and the maximum value was $3.94 \log \mathrm{CFU} \mathrm{g}^{-1}$ at the process start of lot $\mathrm{D}_{2}$. The general trend is clearly decreasing (in the case of lot $\mathrm{C}_{1}$ counts are irregular). In lots $\mathrm{B}_{1}$ and $\mathrm{E}_{3} E$. coli was not detected. The counts of these microorganisms were always lower than the tolerance limits established in the current national legislation for product A.

In the case of other Gram-negative bacteria of the enterobacteria group not identified in the above mentioned groups, counts show irregular values with a general decreasing trend.

\subsection{Enterococci}

Enterococci were isolated in the two first analysis of lot $A_{1}$ with a maximum value of $2.66 \log \mathrm{CFU} \mathrm{g}^{-1}$. In lot $\mathrm{A}_{2}$ their presence was detected in all the samples corresponding to the second and third analysis with a maximum value of 2.04. In lot $A_{3}$, all the samples show similar counts with a of maximum value about $3.00 \log \mathrm{CFU} \mathrm{g}^{-1}$. The species isolated were, in a similar percentage, Enterococcus faecium and Enterococcus faecalis.

For product $\mathrm{B}$, enterococci counts were constant and elevated during the whole process, reaching $4.18 \log \mathrm{CFUg} \mathrm{g}^{-1}$ in the second analysis of lot $\mathrm{B}_{1}$ and $2.63 \log \mathrm{CFU} \mathrm{g}^{-1}$ in the third analysis of lot $\mathrm{B}_{3}$. In lot $\mathrm{B}_{2}$, occurrence of enterococci was constant in all the samples although a downward trend was observed in those counts. The species detected were the same as in product $\mathrm{A}$.

For product C, enterococci (E. faecalis and E. faecium) were detected in the first analysis of lot $\mathrm{C}_{1}$ with a mean of $1.56 \log \mathrm{CFU} \mathrm{g} \mathrm{g}^{-1}$. In lot $\mathrm{C}_{2}$ they were found in the second and third analyses with means of 4.29 and $2.43 \log \mathrm{CFU} \mathrm{g}^{-1}$, respectively. Also, in lot $\mathrm{C}_{3}$ their presence was constant in all the samples with relatively homogeneous values of about $4 \log \mathrm{CFU} \mathrm{g}^{-1}$ at the end of the process. A high level of enterococci, therefore, was observed even in the final product caused by the resistance of these 
species to drying and low $\mathrm{pH}$. This aspect helps these microorganisms to reach higher percentages in some cases.

In lot $\mathrm{D}_{1}$, enterococci were only detected in the finished product. Also, in the case of lot $\mathrm{D}_{2}$, they were found in the second part of the process (in the second control and in the finished product). Lot $\mathrm{D}_{3}$ showed counts of $2.46 \log \mathrm{CFU} \mathrm{g}{ }^{-1}$ for the fresh product and $2.36 \log \mathrm{CFU} \mathrm{g} \mathrm{g}^{-1}$ after the first ripening stage.

No enterococci were detected in any of the samples investigated for products $\mathrm{E}$ and $\mathrm{F}$.

\subsection{Yeasts}

Occurrence of yeasts was notable in most of the samples studied (94.4\%). The evolution in counts was irregular, depending on the initial level of contamination, product type (raw material), $\mathrm{pH}$ and humidity in each case as well as the possible competition with other microorganisms.

In product $\mathrm{A}$, the most numerous group of contaminating microorganisms in all cases were yeasts the counts of which were more or less unchanged. Thus in lot $A_{1}$ counts were about $4 \log \mathrm{CFU} \mathrm{g}^{-1}$ with a slight decrease at the end of the ripening. In lot $\mathrm{A}_{2}$ the values were very similar throughout the ripening process $(3.94,3.74$ and $3.95 \log \mathrm{CFU} \mathrm{g}^{-1}$ ). In lot $\mathrm{A}_{3}$ the highest counts were obtained in the second analysis, reaching $4.74 \log \mathrm{CFU} \mathrm{g}^{-1}$.

In lots $\mathrm{B}_{1}$ and $\mathrm{B}_{3}$ yeasts underwent an important increase throughout the ripening process, reaching $6.13 \log \mathrm{CFU} \mathrm{g}^{-1}$ in the second step of the process of lot $\mathrm{B}_{1}$ and $3.47 \log \mathrm{CFU} \mathrm{g}^{-1}$ in the third analyse of lot $\mathrm{B}_{3}$.

Yeasts were detected in $66 \%$ of the samples investigated from lot $\mathrm{C}_{3}$ with a maximum value of $5.65 \log \mathrm{CFU} \mathrm{g}{ }^{-1}$ in the fresh product. In the final product, $3.83 \log \mathrm{CFU} \mathrm{g}^{-1}$ were obtained. For lot $\mathrm{C}_{2}$, counts were lower and did not show changes during the ripening period. In lot $\mathrm{C}_{3}, 100 \%$ of the samples were positive but the counts decreased throughout the ripening period.

Yeasts were detected in $100 \%$ of the samples of product $D$. In lot $D_{1}$ counts were clearly decreasing through the ripening process. The results of the fresh product of lot $\mathrm{D}_{2}$ were very similar to those of the previous lot, reaching in this case a maximum in the second analysis. The final product counts were reduced in half. Lot $\mathrm{D}_{3}$ showed counts lower than the lots mentioned before and a slight increasing trend.

Among the contaminant microorganisms studied, the constant presence of yeasts was notable in all the samples of product $\mathrm{E}$ with a progressive increase in counts throughout the ripening period. This may be due to the reduction in $\mathrm{pH}$ experienced by the product during the ripening process since low $\mathrm{pHs}$ can improve the competitiveness of these microorganisms. 
In product $F$ there were yeasts in all the samples studied. In lots $F_{1}$ and $F_{3}$ a progressive increase in these microorganisms' counts was detected throughout the ripening period, being this increase of about 2 logarithmic units.

\subsection{Listeria spp., Salmonella spp. and Clostridium spp.}

The species Salmonella arizonae was isolated in a sample of the unripened product in lot $\mathrm{A}_{3}$, but at the end of the ripening period it was no longer detected. Listeria spp. was also detected in another sample of the unripened product in the same lot. The current national legislation of the country of origin establishes a microbiological tolerance limit in unripened products and this was exceeded in three of the samples in lot $\mathrm{A}_{3}$ since in one of them Salmonella was detected, and in another Listeria. Therefore, some corrective measures should be taken in order to improve the hygienic quality of this product. In the final product, no Salmonella or Listeria were detected. Finally, all the samples gave negative results when these were checked for sulphite-reducing Clostridium.

No Salmonella-Shigella or L. monocytogenes were isolated in any of the samples investigated for product D. However, the presence of clostridia, concretely Clostridium perfringens, was detected in this product. So, two samples of the unripened product in the case of lot $\mathrm{D}_{1}$ and the three samples of the initial product in lot $\mathrm{D}_{2}$ were positive. In the case of lot $\mathrm{D}_{1}$, two positive samples with 1 and $1.70 \log \mathrm{CFU} \mathrm{g}{ }^{-1}$ occurred. In lot $\mathrm{D}_{2}$, the mean value considered was $1.99 \log \mathrm{CFU} \mathrm{g}^{-1}$.

No Salmonella-Shigella, sulphite-reducing Clostridium or L. monocytogenes were detected in products $\mathrm{B}, \mathrm{C}, \mathrm{E}$ and $\mathrm{F}$.

The presence of contaminant biota in the final product was restricted to yeasts (present in the 6 products studied) and enterococci (in products A, B, C and D) as these were microbe groups with a high resistance to elevated levels of acidity and reduced $\mathrm{a}_{\mathrm{w}}$. In products $\mathrm{A}, \mathrm{B}, \mathrm{C}$ and $\mathrm{D}$, yeasts and enterococci values were elevated in a high percentage of the samples, even in the finished product. SAMELIS and co-workers (1993) found that counts of yeasts remained stable in all the stages at a level of $5 \log \mathrm{CFU} \mathrm{g}^{-1}$ for both analysed lots.

In a study on salami of Naples of artisan production (COPPOLA et al., 1995) enterococci decreased to a constant number of $1 \log \mathrm{CFU} \mathrm{g}{ }^{-1}$ after 15 days from an initial value of about $4 \log \mathrm{CFU} \mathrm{g}{ }^{-1}$. Also yeasts (initial value of about $3 \log \mathrm{CFU} \mathrm{g}{ }^{-1}$ ) progressively decreased. The progressive reduction of enterococci and enterobacteria that was observed, optimal for this type of product, was probably due to competition factors and inhibitory conditions.

DIAFERIA and co-workers (1995) also studied the contamination in salami and they found a gradual decrease in the counts of Enterobacteriaceae and other Gram-negative microorganisms during the ripening process. GARCÍA and co-workers 
(1998) and RoIG and co-workers (1998) found a decreasing trend in Enterobacteriaceae counts until disappearing in different traditional fermented sausages. This behaviour is typical of products that have been correctly matured and dried. In fact, the fast development of lactic acid bacteria and the consequent production of lactic acid cause a reduction of $\mathrm{pH}$ and a progressive inactivation of the Gram-negative bacteria.

In relation to the counts of yeasts, DIAFERIA and co-workers (1995) found in salami a decreasing trend up to the end of the process or they remained constant in the case of low initial levels. These results agree partially with those obtained by SMITH and Palumbo (1973) and Palumbo and co-workers (1976) that show a reduction in the counts of Enterobacteriaceae and yeasts during fermentation, probably because of these microorganisms are sensitive to the acid environment of sausages. Similarly DOMÍNGUEZ and co-workers (1989) found also a reduction in the number of Enterobacteriaceae during the process of ripening, or they even disappeared. On the other hand the number of yeasts increased during the first days of the process of ripening, and afterwards it remained constant until the end of the process.

In Greek salami, SAMELIS and co-workers (1994) found, as we did in some lots, high levels of yeasts that exceeded in all the cases the $5 \log \mathrm{CFU} \mathrm{g}^{-1}$ in the ripening product. The counts of yeasts obtained by PALUMBO and co-workers (1976) in pepperoni oscillated between $2 \log \mathrm{CFU} \mathrm{g}^{-1}$ and $5 \log \mathrm{CFU} \mathrm{g}{ }^{-1}$. Coliforms were not detected in any of the samples analysed.

Regarding to enterococci, DIAFERIA and co-workers (1995) did not find a meaningful variation in counts of this group of microorganisms. GARCíA and co-workers (1998) found high levels of these microorganisms both in artisanal and industrial processing of a Spanish traditional fermented sausage, that remained during the ripening period. At the end of the process counts were 4.70 and $6.48 \log$ CFU g ${ }^{-1}$ respectively. Also, RoIG and co-workers (1998) found enterococci in another traditional ripened sausage, where counts increased during the first four days remaining then constant (maximum value reached $5.88 \log \mathrm{CFU} \mathrm{g}^{-1}$ ). In these cases, counts were generally higher than those obtained by us in six types of dry-sausages, but the behaviour of these microorganisms is similar in evolution and they can survive up to the end of the process. In our opinion, the investigation of enterococci is very useful in the control of the hygienic quality of the raw material.

The survival of Salmonella in sausages is only possible when the $\mathrm{pH}$ of the product is not sufficiently low and the humidity is elevated. An outbreak of salmonellosis caused by fermented pork sausages with a pH of 5.7 and $\mathrm{a}_{\mathrm{w}}$ of 0.99 was reported by VAN NETTEN and co-workers (1986).

We have confirmed the presence of Salmonella, sulphite-reducing clostridia and Listeria in some samples of fresh product. According to MORENO and co-workers (1993) in spite of more or less constant presence of Salmonella in this product, the 
outbreaks of salmonellosis by consumption of dry sausages are very unusual, being more frequent in fresh sausages because of the initial contamination of the raw material. Also L. monocytogenes is often isolated in this type of products.

Thus an improvement could be desirable in the hygienic quality of the raw material of some of the dry-sausages studied because of the occurrence of potential pathogens in the first stage of the process was detected. In fact, the current legislation of some countries of the South of EU gives specifications for raw meat used to evaluate sausages as far as Salmonella spp., Listeria spp., E. coli, etc. are concerned. On the other hand, we have to take into account that this process leads to a meat derivative which undergoes a process of fermentation and drying, and we confirmed that the final products analysed showed an acceptable state of food safety in all cases.

The work reported here was carried out in the course of the DRIP project. This project is funded by the FAIR Programme of the Commission of the European Communities with the project number 96-1220. This paper represents the authors' point of view and does not necessarily reflect that of the DRIP Consortium.

\section{References}

ANON (1995): Escherichia coli O157:H7 outbreak linked to commercially distributed dry-cured salami. Centers for Disease Control and Prevention. Washington and California, 1994. Morbid. Mortal Weekly Rep., 44, 157-160.

ADAMS, M. R. \& Moss, M. O. (1997): Microbiología de los alimentos. (Food microbiology.) Acribia, Zaragoza, pp. 351-354.

BACUS, J. N. \& BROWN, W. L. (1981): Use of microbial cultures: meat products. Fd Technol., 35(1), 74-78.

BELLO, J. \& SÁNCHEZ, M. A. (1995): Application of a mathematical model for the inhibition of Enterobacteriaceae and clostridia during a sausage curing process. J. Fd Prot., 58, 1345-1350.

CANTONI, C. C., BAIZARETTI, C. C. \& VALENTI, M. (1989): A case of Listeria monocytogenes human infection associated with consumption of "testa in cascetta" (cooked meat pork product) Arch. Vet. Ital., 40, 141-142.

COPPOLA, R., MARCONI, E., ROSSI, F. \& DELLAGLIO, F. (1995): Artisanal production of Napoles-type salami: chemical and microbiological aspects. Italian. J. Fd Sci., 1, 57-62.

DiAFERIA, C., PIRONE, G., LA PIETRA, L. \& MAGLIANO, V. (1995): Impego di microorganismi autoctoni nella preparazione del salame stagionato. I. Caratteristiche chimico-fisiche e microbiologiche in funzione del tipo e del livello di zucchero. (Role of authoctonous microflora on the ripening of sausages. I. Physical-chemical and microbiological characteristics on the basis of sugar level and type.) Industria Conserve, 70, 138-143.

DOMínGUEZ, M. C., GUTIÉRRFZ, L. M., LÓPEZ, A., SECO, F. \& ZUMALACÁRREGUI, J.M. (1989): Evolución de los principales grupos de microorganismos durante la maduración del chorizo de León. (Evolution of the main microbiological groups during the ripening of León's "chorizo".) Alimentaria, 199, 11-15. 
FAith, N. G., PARNiere, N., LARSON, T., LORANG, T. D. \& LUCHANSKY, J. B. (1997): Viability of Escherichia coli $\mathrm{O} 157: \mathrm{H} 7$ in pepperoni during the manufacture of sticks and subsequent storage of slices at 21,4 and $-20^{\circ} \mathrm{C}$ under air, vacuum and $\mathrm{CO}_{2}$. Int. J. Fd Microbiol., 37, 47-54.

FARBER, J., TITTIGER, M. \& GOUR, L. T. (1988): Surveillance of raw-fermented dry-cured sausages for the presence of Listeria spp. Can. Inst. Fd Sci. Technol. J., 21, 430-434.

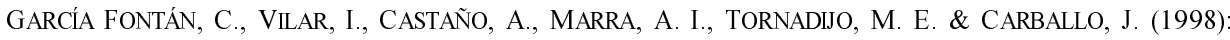
Microbiological changes during ripening of "Chorizo de cebolla", a traditional fermented sausage made in the NW of Spain. 44th ICOMST "Meat consumption and culture". Congress proceedings, pp. 838-839.

HugAS, M., GARRIGA, M., AYMERICH, M. T. \& MONFORT, J. M. (1995): Inhibition of Listeria in dry fermented sausages by the bacteriocinogenic Lactobacillus sake CTC494. J. appl. Bacteriol., 79, $322-330$.

JOHNSON, J. L., DOYLE, M. P., CASSENS, R. G. \& SCHOENI, J. L. (1988): Fate of Listeria monocytogenes in tissues of experimentally infected cattle and in hard salami. Appl. environ. Microbiol., 54, 497-501.

LOVETT, J. (1989): Listeria monocytogenes. -in: DOYLE, M. P. (Ed.). Foodborne bacterial pathogens. Marcel Dekker, New York, pp. 283-310.

LÜCKE, F. K. (1994): Fermented meat products. Fd Res. int., 27, 299-307.

MORENO, B., GONZÁLEZ, M. E., GONZÁLEZ, C. \& ROMÁN, M. C. (1993): El sistema de análisis de riesgos e identificación y control de puntos críticos. Procedimiento para asegurar la inocuidad y la calidad higiénica de los embutidos crudos curados. (Hazard analysis and critical control points system. Procedures to guarantee the wholesomeness and hygienic quality of dry-sausages.) Cárnica 2000, 112, 33-39.

NOUT, M. J. R. (1994): Fermented foods and food safety. Fd Res. int., 27, 291-298.

PALUMBO, S. A., ZAIKA, L. L., KISSINGER, J. C. \& SMITH, J. L. (1976): Microbiology and technology of the pepperoni process. J. Fd Sci., 41, 12-17.

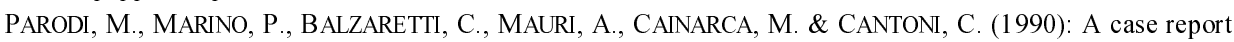
of sporadic listeriosis related to pork meat in healthy man. G. Mal. Infett. Parassit., 42, 115-116.

POZO, R. (1985): Microbiología de los productos cárnicos. (Microbiology of meat products.) Lecture presented in "Food Microbiology" course organised by the Veterinary Official Professional College of Navarra (Spain).

ROIG, A. X., HERNÁNDEZ, M. M., RODRÍGUEZ, J. J., LÓPEZ, E. I. \& MORA, M. T. (1998): Microbiological events and evolution of Histidine and Tyrosine decarboxylase-containing bacteria during the elaboration of "fuet", a Spanish ripened sausage. 44th ICOMST "Meat consumption and culture". Congress proceedings, pp. 860-861.

SAMELIS, J., AGGELIS, G. \& METAXOPOULUS, J. (1993): Lipolytic and microbial changes during the natural fermentation and ripening of Greek dry sausages. Meat Science, 35, 371-385.

SAMElis, J., StAVROPOUlOS, S., KAKOURI, A. \& METAXOPOUluS, J. (1994): Quantification and characterization of microbial populations associated with naturally fermented Greek dry salami. $F d$ Microbiol., 11, 447-460.

SMITH, J. L. \& PALUMBO, S. A. (1973): Microbiology of Lebanon Bologna. Appl. Microbiol., 26, 489-496.

TRUSSEL, M. \& JEMMI, T. (1989): The behaviour of Listeria monocytogenes during the ripening and storage of artificially contaminated salami and Mettwurst. Fleischwirtschaft, 69, 1586-1592.

VALLADARES, C., ROCA, M., RAMOS, R. \& GONZÁLEZ, E. (1993): Efecto del proceso tecnológico sobre la Salmonella en productos crudos fermentados. (Effect of technological process on Salmonella in drysausages.) Alimentaria, 245, 33-35.

VAN NetTen, P., LeEnAerts, J., HeIKANT, G. M. \& MOSSEL, D. A. A. (1986): A minor outbreak of salmonellosis caused by fermented pork sausage. Tijdschrift voor Diergeneeskunde, 111, 1271-1275. 